\begin{tabular}{|l|}
\hline Access this article online \\
\hline Quick Response Code: \\
\hline Website: \\
www.jponline.org \\
\hline DOI: \\
10.4103/JLP.JLP_57_19 \\
\hline
\end{tabular}

Departments of Microbiology and ${ }^{1}$ CTVS, All India Institute of Medical Sciences, New Delhi, India

Address for correspondence: Dr. Benu Dhawan,

Department of Microbiology, All India Institute of Medical Sciences, New Delhi - 110 029, India. E-mail: dhawanb@gmail. com

Submission: 05-04-2019 Accepted: 16-06-2019

\title{
Pleural effusion due to Chryseobacterium indologenes: Case report and review of literature
}

\author{
Nazneen Arif, Swati Khullar, Ratnesh Kumar ${ }^{1}$, Shiv Kumar Choudhary ${ }^{1}$, Arti Kapil, \\ Benu Dhawan
}

\section{Abstract:}

Chryseobacterium indologenes is found ubiquitously in the environment; it rarely causes human disease. Hence, we report a case of $C$. indologenes-associated pleural effusion in a patient with aortic dissection. Postoperatively, the patient developed massive right-sided pleural effusion with underlying consolidated lung. Culture of the pleural fluid yielded pure growth of $C$. indologenes which was susceptible to cotrimoxazole, minocycline, and tigecycline. Therapy was modified; tigecycline and cotrimoxazole were started following which the patient showed improvement, and subsequent cultures of the pleural fluid were sterile. This report promotes awareness of this organism as an emerging pathogen in lung infections and emphasizes the importance of targeted therapy.

Keywords:

Aortic dissection, Chryseobacterium indologenes, pleural effusion

\section{Introduction}

C hryseobacterium indologenes is a nonfermenting Gram-negative bacillus which is ubiquitously found in the environment. Recently, an upsurge of C. indologenes nosocomial infections has been reported because of the advances in newer diagnostic modalities, which have made identification of rare nonfermenters easier. ${ }^{[1]}$ We describe a case of $C$. indologenes-associated pleural effusion in a patient with aortic dissection.

\section{Case Report}

A 42-year-old male patient presented to the emergency department with complaints of acute onset of severe chest pain and shortness of breath. There was no trauma or injury to the chest. The patient had no underlying history of

This is an open access journal, and articles are distributed under the terms of the Creative Commons Attribution-NonCommercial-ShareAlike 4.0 License, which allows others to remix, tweak, and build upon the work non-commercially, as long as appropriate credit is given and the new creations are licensed under the identical terms.

For reprints contact: reprints@medknow.com diabetes, immunosuppression, or any other comorbid condition apart from a past history of aortic regurgitation. There was no recent history of hospitalization, indwelling catheters, or invasive procedures. On initial examination, the patient was conscious and well oriented with heart rate of $124 / \mathrm{min}$, blood pressure of $190 / 71 \mathrm{mmHg}$, respiratory rate of $24 / \mathrm{min}$, and $72 \% \mathrm{SpO}_{2}$. Respiratory examination revealed bilateral vesicular breath sounds. All other organ systems were normal on examination. The hematological investigations were normal. Computed tomography aortic angiography revealed Type A aortic dissection with intimal flap extending from the aortic root proximally up to the left common iliac artery distally, and a large entry tear was present in the ascending aorta. The patient underwent a modified Bentall procedure with hemiarch repair and Alfieri mechanical valve (MV) repair for Type A aortic dissection. An initial regimen of meropenem, ofloxacin, and metronidazole was started.

How to cite this article: Arif N, Khullar S, Kumar R, Choudhary SK, Kapil A, Dhawan B. Pleural effusion due to Chryseobacterium indologenes: Case report and review of literature. J Lab Physicians 2019;11:284-6. 
The patient was readmitted after 2 weeks of surgery with high-grade fever $\left(102^{\circ} \mathrm{F}\right)$. Laboratory tests revealed leukocytosis $\left(15,000 / \mathrm{mm}^{3}\right)$ and raised erythrocyte sedimentation rate $(40 \mathrm{~mm}$ at the end of first hour (AEFH)). Blood cultures were sterile. A normally functioning MV was seen on echocardiogram. The patient was started empirically on meropenem and ceftriaxone for possible culture-negative endovascular infection. Within $24 \mathrm{~h}$, the patient developed respiratory difficulty, and ultrasound chest revealed a massive right-sided pleural effusion with underlying consolidated lung. An intercostal drainage was performed, and pleural fluid was sent for bacterial culture.

Culture of the pleural fluid yielded convex, circular, and yellow-colored colonies on 5\% sheep blood agar. Gram stain showed Gram-negative bacilli, which were nonmotile, catalase positive, oxidase positive, indole positive, and glucose nonfermenting. The isolate was further confirmed as C. indologenes by MALDI-TOF MS system (VITEK MS ${ }^{\text {TM}}$; bioMerieux, France) with $99.9 \%$ confidence value of identification. Samples from the patient's surroundings including swabs from the dressing trolley, bed railing, mattress, in-use antiseptic solutions, and intravenous fluids were tested to determine the source of infection. However, all samples were negative for $C$. indologenes.

Despite antimicrobial therapy, leukocytosis and fever persisted. Susceptibility testing was performed using VITEK I automated system (BioMerieux Vitek, Inc.), and the isolate was susceptible to cotrimoxazole, minocycline, and tigecycline and resistant to aminoglycosides, fluoroquinolones, piperacillin/ tazobactam, cefoperazone-sulbactam, third-generation cephalosporins, and carbapenems. Treatment was modified, and tigecycline and cotrimoxazole were started and continued for 10 days. The patient improved, and follow-up cultures of the pleural fluid were sterile. The patient was discharged at the end of the treatment period.

\section{Discussion}

Majority of the infections caused by C. indologenes have been associated with certain predisposing conditions such as immunodeficiency, malignancies, presence of indwelling catheters, and invasive devices. ${ }^{[2,3]}$ Our patient was immunocompetent. Surgical intervention could be the predisposing factor for acquisition of this infection. Isolation of this organism from a sterile site, absence of other pathogens, and response to treatment suggest that $C$. indologenes was responsible for pleural effusion in this case. Environmental screening failed to detect the source of infection. Although the biological sequence of events is unknown, the organism was possibly inoculated through a breach in the skin at the time of the surgery, possibly giving rise to a transient bacteremia and seeding into the pleural cavity.

C. indologenes presents with a high rate of resistance against commonly used antibiotics such as aminoglycosides, chloramphenicol, penicillins, aztreonam, cephalosporins,

Table 1: Respiratory system infections caused by Chryseobacterium indologenes in adult patients

\begin{tabular}{|c|c|c|c|c|c|c|}
\hline Years & Country & Age/sex & Possible predisposing condition & Sample & Outcome & References \\
\hline 2018 & India & 68/female & $\begin{array}{l}\text { Connective tissue disorder, interstitial } \\
\text { lung disease }\end{array}$ & ET aspirate & Expired & $\begin{array}{l}\text { Agarwal et al., Indian J Crit Care Med } \\
2018^{[6]}\end{array}$ \\
\hline 2017 & Turkey & $69 /$ male & COPD & Sputum & Improved & $\begin{array}{l}\text { Soydan et al., Drug Discov Ther } \\
2017^{[7]}\end{array}$ \\
\hline 2017 & Japan & 64/female & Adult T-cell leukemia/lymphoma & Sputum & Expired & $\begin{array}{l}\text { Imataki and Uemura Clin Case Rep } \\
2017^{[8]}\end{array}$ \\
\hline 2016 & Spain & NA & NA & NA & NA & $\begin{array}{l}\text { Chiscano-Camón et al., Med } \\
\text { Clin (Barc) 2016 }\end{array}$ \\
\hline 2016 & Spain & 63/female & $\begin{array}{l}\text { Parietal oligodendroglioma } \\
\text { postsurgery, chemotherapy, } \\
\text { radiotherapy }\end{array}$ & BAL & Improved & Peñasco et al., Med Intensiva $2016^{[10]}$ \\
\hline 2015 & Turkey & $82 /$ male & NA & $\begin{array}{l}\text { Transtracheal } \\
\text { aspirate }\end{array}$ & Improved & $\begin{array}{l}\text { Nemli et al., Case Rep Infect Dis } \\
2015^{[11]}\end{array}$ \\
\hline 2015 & Tunisia & NA & NA & NA & NA & $\begin{array}{l}\text { Ben Salah et al., Rev Pneumol Clin } \\
2015^{[12]}\end{array}$ \\
\hline 2014 & India & $42 /$ male & Gastric non-Hodgkin's lymphoma & Sputum & $\begin{array}{l}\text { Improved } \\
\text { initially }\end{array}$ & Shahul et al., BMJ Case Rep 2014[13] \\
\hline 2013 & USA & $66 /$ male & Trauma & BAL & Improved & $\begin{array}{l}\text { Monteen et al., Ann Pharmacother } \\
2013^{[14]}\end{array}$ \\
\hline 2013 & USA & 32/female & Metastatic breast cancer & Tracheal aspirates & Expired & $\begin{array}{l}\text { Yasmin et al., J Med Case Rep } \\
2013^{[15]}\end{array}$ \\
\hline 2010 & Brasil & $30 /$ male & $\begin{array}{l}\text { Idiopathic medullary aplasia, febrile } \\
\text { neutropenia }\end{array}$ & Tracheal aspirate & NA & $\begin{array}{l}\text { Ferreira Rde et al., Rev Bras Ter } \\
\text { Intensiva 2010[16] }\end{array}$ \\
\hline 2007 & France & NA & NA & NA & NA & Reynaud et al., Med Mal Infect $2007^{[17]}$ \\
\hline
\end{tabular}

$\mathrm{COPD}=$ Chronic obstructive pulmonary disease, $\mathrm{BAL}=$ Bronchoalveolar lavage, ET aspirate=Endotracheal aspirate, NA=Data not available 
and carbapenems. Since the $C$. indologenes isolate was multidrug resistant, our patient did not respond to the empirical antibiotic therapy. The most often found active agents are newer fluoroquinolones, minocycline, cefepime, and cotrimoxazole. ${ }^{[3-5]}$ Our patient responded well to a combination of tigecycline and cotrimoxazole.

We searched the PubMed database for infections of the respiratory system caused by $C$. indologenes in adults and found 12 case reports [Table 1] and four studies. ${ }^{[5,18-20]}$ To the best of our knowledge, this is the first report of pleural effusion due to $C$. indologenes in an immunocompetent individual with preexisting heart disease. This case further expands the clinical spectrum of this opportunistic pathogen. The choice of empirical therapy in such conditions also becomes important since most of these pathogens are multidrug resistant.

\section{Conclusion}

Our report suggests that the pathogenicity and clinical significance of $C$. indologenes should not be underestimated. Prompt, appropriate-targeted antimicrobial therapy ensures a favorable outcome. Identification of the source of infection should be attempted wherever possible, as this will have implications for infection control.

\section{Declaration of patient consent}

The authors certify that they have obtained all appropriate patient consent forms. In the form the patient(s) has/ have given his/her/their consent for his/her/their images and other clinical information to be reported in the journal. The patients understand that their names and initials will not be published and due efforts will be made to conceal their identity, but anonymity cannot be guaranteed.

\section{Financial support and sponsorship Nil.}

\section{Conflicts of interest}

There are no conflicts of interest.

\section{References}

1. Cunha V, Ferreira M, Fonseca AG, Diogo J. Community-acquired Chryseobacterium indologenes in an immunocompetent patient. JMM Case Reports 2014;1:1-2.

2. Nulens E, Bussels B, Bols A, Gordts B, Van Landuyt HW. Recurrent bacteremia by Chryseobacterium indologenes in an oncology patient with a totally implanted intravascular device. Clin Microbiol Infect 2001;7:391-3.

3. Fraser SL, Jorgensen JH. Reappraisal of the antimicrobial susceptibilities of Chryseobacterium and Flavobacterium species and methods for reliable susceptibility testing. Antimicrob Agents Chemother 1997;41:2738-41.

4. Chang JC, Hsueh PR, Wu JJ, Ho SW, Hsieh WC, Luh KT. Antimicrobial susceptibility of flavobacteria as determined by agar dilution and disk diffusion methods. Antimicrob Agents Chemother 1997;41:1301-6.

5. Chang YC, Lo HH, Hsieh HY, Chang SM. Identification, epidemiological relatedness, and biofilm formation of clinical Chryseobacterium indologenes isolates from central Taiwan. J Microbiol Immunol Infect 2015;48:559-64.

6. Agarwal S, Kakati B, Khanduri S. Severe sepsis due to Chryseobacterium indologenes, a possible emergent multidrug-resistant organism in intensive care unit-acquired infections. Indian J Crit Care Med 2018;22:817-9.

7. Soydan S, Ignak S, Unay Demirel O, Karadağ G, Aykent A, Aslan S. Chryseobacterium indologenes infection in a patient with chronic obstructive pulmonary disease. Drug Discov Ther 2017;11:165-7.

8. Imataki O, Uemura M. Chryseobacterium indologenes, a possible emergent organism resistant to carbapenem antimicrobials after stem cell transplantation. Clin Case Rep 2017;5:22-5.

9. Chiscano-Camón L, Ruiz-Rodríguez JC, Alcaraz R, Ferrer R. Ventilator-associated pneumonia by Chryseobacterium indologenes. Med Clin (Barc) 2016;146:e61-2.

10. Peñasco Y, Duerto J, González-Castro A, Domínguez MJ, Rodríguez-Borregán JC. Ventilator-associated pneumonia due to Chryseobacterium indologenes. Med Intensiva 2016;40:66-7.

11. Nemli SA, Demirdal T, Ural S. A case of healthcare associated pneumonia caused by Chryseobacterium indologenes in an immunocompetent patient. Case Rep Infect Dis 2015;2015:483923.

12. Ben Salah I, Fekih Hassen M, Ben Haj Khalifa A, Ben Sik Ali H, Tilouche N, Kheder M, et al. Chryseobacterium indologenes in ventilator-associated pneumonia: First reported case in Tunisia. Rev Pneumol Clin 2015;71:374-5.

13. Shahul HA, Manu MK, Mohapatra AK, Chawla K. Chryseobacterium indologenes pneumonia in a patient with non-Hodgkin's lymphoma. BMJ Case Rep 2014;2014. pii: bcr2014204590.

14. Monteen MR, Ponnapula S, Wood GC, Croce MA, Swanson JM, Boucher BA, et al. Treatment of Chryseobacterium indologenes ventilator-associated pneumonia in a critically ill trauma patient. Ann Pharmacother 2013;47:1736-9.

15. Yasmin S, Garcia G, Sylvester T, Sunenshine R. Chryseobacterium indologenes in a woman with metastatic breast cancer in the United States of America: A case report. J Med Case Rep 2013;7:190.

16. Ferreira Rde S, Brandão FF, Lobo SM. Chryseobacterium indologenes infection: A case report. Rev Bras Ter Intensiva 2010;22:96-8.

17. Reynaud I, Chanteperdrix V, Broux C, Pavese P, Croizé J, Maurin $\mathrm{M}$, et al. A severe form of Chryseobacterium indologenes pneumonia in an immunocompetent patient. Med Mal Infect 2007;37:762-4.

18. Jain V, Sahu C, Afzal Hussain NA, Ghar M, Prasad KN. The era of device colonizers: Chryseobacterium indologenes infections from a tertiary care center in North India. Indian J Crit Care Med 2018;22:537-40.

19. Hsueh PR, Teng LJ, Yang PC, Ho SW, Hsieh WC, Luh KT. Increasing incidence of nosocomial Chryseobacterium indologenes infections in Taiwan. Eur J Clin Microbiol Infect Dis 1997;16:568-74.

20. González-Castro A, Alsasua A, Peñasco Y, Rodríguez JC, Duerto J. Tracheo-bronchitis and pneumonia associated with mechanical ventilation by Chryseobacterium indologenes. Rev Esp Anestesiol Reanim 2017;64:294-8. 